\title{
Sedimentological Origin and Environmental Impact of El Zayat Shales, East Dakhla Oasis, Western Desert, Egypt
}

\author{
Zidan I.H., Osman R.A. and Mansour G.M.R.
}

Nuclear Materials Authority, P.O. Box 530 El Maadi, Cairo, Egypt

\section{Received: 15 Dec. 2019/ Accepted 20 Feb. 2020 / Publication date: 10 Mar. 2020}

\begin{abstract}
Twenty representative shale samples were collected from a vertical lithostratigraphic section including (Quseir Shale Member of Nubia Formation, Duwi Formation and Dakhla Formation) of El Zayat area on the southern scarp at the central part of the Abu Tartur Plateau.The chemical analyses data show that the average values of $\mathrm{V} / \mathrm{Cr}$ in the studied shales are higher than 2 , which may indicate that all of the studied sediments were deposited under anoxic depositional conditions. The $\mathrm{Cr} / \mathrm{Ni}$ ratios of El Zayat shales are 1.5, may be reflect these sediments are derived from mafic source rocks. The tectonic setting studies indicated that the investigated studied shales were mainly derived from volcanic rocks with province origin. The chemical Index of alteration (CIA) was calculated for all the samples and revealed that El Zayat shales describe the moderate chemically weathered terrain. Beside, the fluviatile of post deposition contributions from local sources, such as the basement rocks in the Egyptian South Western Desert, can be considered as subordinate sources. The immobile elements are also indicators of the origin of the provenance. Therefore, the presence of trace elements $\mathrm{Cr}, \mathrm{V}$ and $\mathrm{Ni}$ in addition to $\mathrm{Ti}$ in $\mathrm{El}$ Zayat shales suggests a basaltic source origin. Additional environmental investigations were also undertaken in order to explore any environmental radiation impact that may arise from the utility of these shales in any domestic purposes by the locals and/or industry. The calculation of geo-accumulation indices (Igeo) indicate that the investigated sediment in El Zayat area is mainly low to moderately pollute. However, their utility in domestic purposes is safe if the dilution factor in the final product is proper.
\end{abstract}

Keywords: Dakhla Oasis, El Zayat area, Quseir Shale, Duwi Formation, Shale, Deposits.

\section{Introduction}

El Zayat area extends in an east-west trend about $13 \mathrm{~km}$ long on the boundary of the southern scarp of the central part of the Abu Tartur Plateau, which is located at about $15 \mathrm{~km}$ north DakhlaKharga road, East Dakhla Oasis (Fig. 1). The Campanian - Maestrichtian sedimentary succession of variegated and black shales are widely distributed in Upper Egypt. This succession laterally extends from the New Valley in the Western Desert to Safaga-El Quseir region on the Red Sea Coastal plain through Sibaiya at Nile Valley.

El Zayat area, contains an occurrence of extensive black shale beds of Duwi Formation that overlie a fluvial variegated shale sequence in Quseir Member of Nubia Formation, with an undulating erosion contact. The entire succession is conformably overlain by the deeper marine laminated grey to black shales of the Dakhla Formation. Zidan (2002) suggested that the montmorillonite and kaolinite minerals with a minor part of illite and chlorite are dominant in variegated and black shales of the Abu Tartur area. Also, the kaolinite and montmorillonite minerals are the main constitute of variegated and black shales of Sibaiya area (Zidan and Osman, 2014).

Generally, the Clay minerals in marine sediments have been used to infer paleo-environmental conditions (Jeong and Yoon, 2001). In continental weathering environments, smectite and kaolinite are generally formed by active chemical weathering of rocks under humid temperate to tropical climates (Weaver, 1989). Smectite and kaolinite occurrence in marine sediments was often ascribed to the chemical weathering in a warm humid environment. Smectite can also form diagenetically from illite, kaolinite, or chlorite (Moore and Reynolds, 1989). The kaolinite formation is favored under tropical to subtropical humid climatic conditions (Hallam et al., 2005). In addition to its detrital origin, kaolinite may also be developed by digenetic processes due to the circulation of acid solutions

Corresponding Author: Zidan I.H., Nuclear Materials Authority, P.O. Box 530 El Maadi, Cairo, Egypt. E-mail:dr.01097960113@yahoo.com. 
(Ghandour et al., 2005). Zidan and Osman (2014) suggested that the origin of Sibaiya shale has been interpreted, for a long time, as a product of chemical weathering of basaltic source.

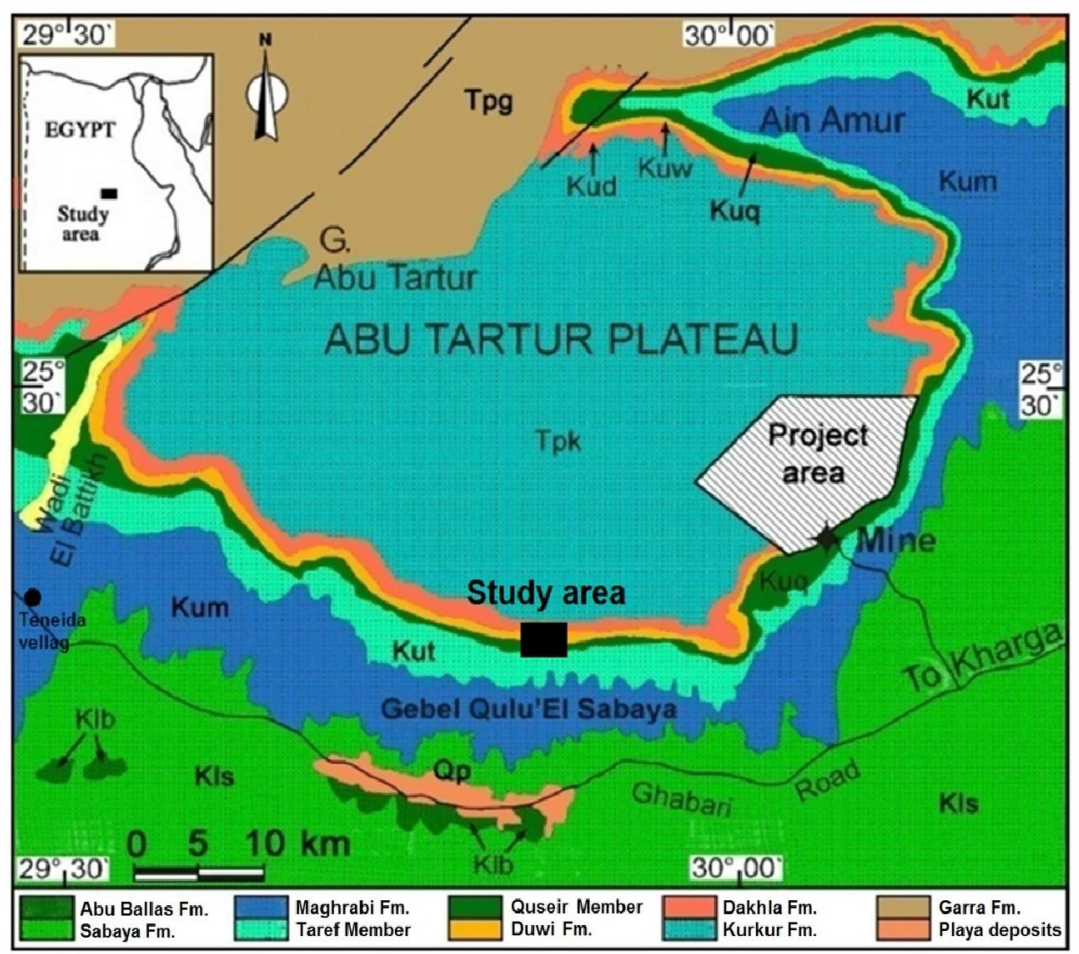

Fig. 1: Location map of the studied El Zayat area, East of Dakhla Oasis.

\section{Geologic setting:}

The exposed lithostratigraphic succession in El Zayat area, on the boundary of the southern scarp of the central part of the Abu Tartur Plateau, was described and classified according to Issawi et al. (1999) based by Quseir shale Member of Nubia Formation, Duwi Formation and Dakhla Formation at the top (Fig. 2).

\section{The Quseir shale Member}

The Quseir shale Member of Nubia Formation is well exposed in El Zayat area and composed of different variegated shales, reddish brown, green, grey and yellow in colour, intercalated with siltstone beds. The surface thickness of this member ranges from 10 to $25 \mathrm{~m}$ averaging $20 \mathrm{~m}$ (Figs. 2 and 3). Zidan (2002) suggested that the total thickness of this member at Abu Tartur area is up to $80 \mathrm{~m}$.

\section{The Duwi Formation}

The Duwi Formation composes three members according of Issawi et al. (1978 and 1999) and Zidan (2014 and 2017) as follows:

\section{The Lower Phosphorite Member}

This member consists of a yellowish brown phosphorite, intercalated with dolomitic phosphorite and grey shale lenses. These lenses vary in thickness from 0.2 to $0.6 \mathrm{~m}$ with an average $0.4 \mathrm{~m}$ thick. The total thickness of this member ranges from 2 to $3.5 \mathrm{~m}$ with an average of $3 \mathrm{~m}$ which could be considered the economic phosphorite beds in the studied area (Fig. 2).

\section{The Middle Shale Member}

This member is mainly composed of papery black to grey shale, cracked and filled with gypsum and ferruginous staining. This member has total thickness ranges from 2 to $8 \mathrm{~m}$ with an average $6 \mathrm{~m}$ (Figs. 2 and 4 ). 


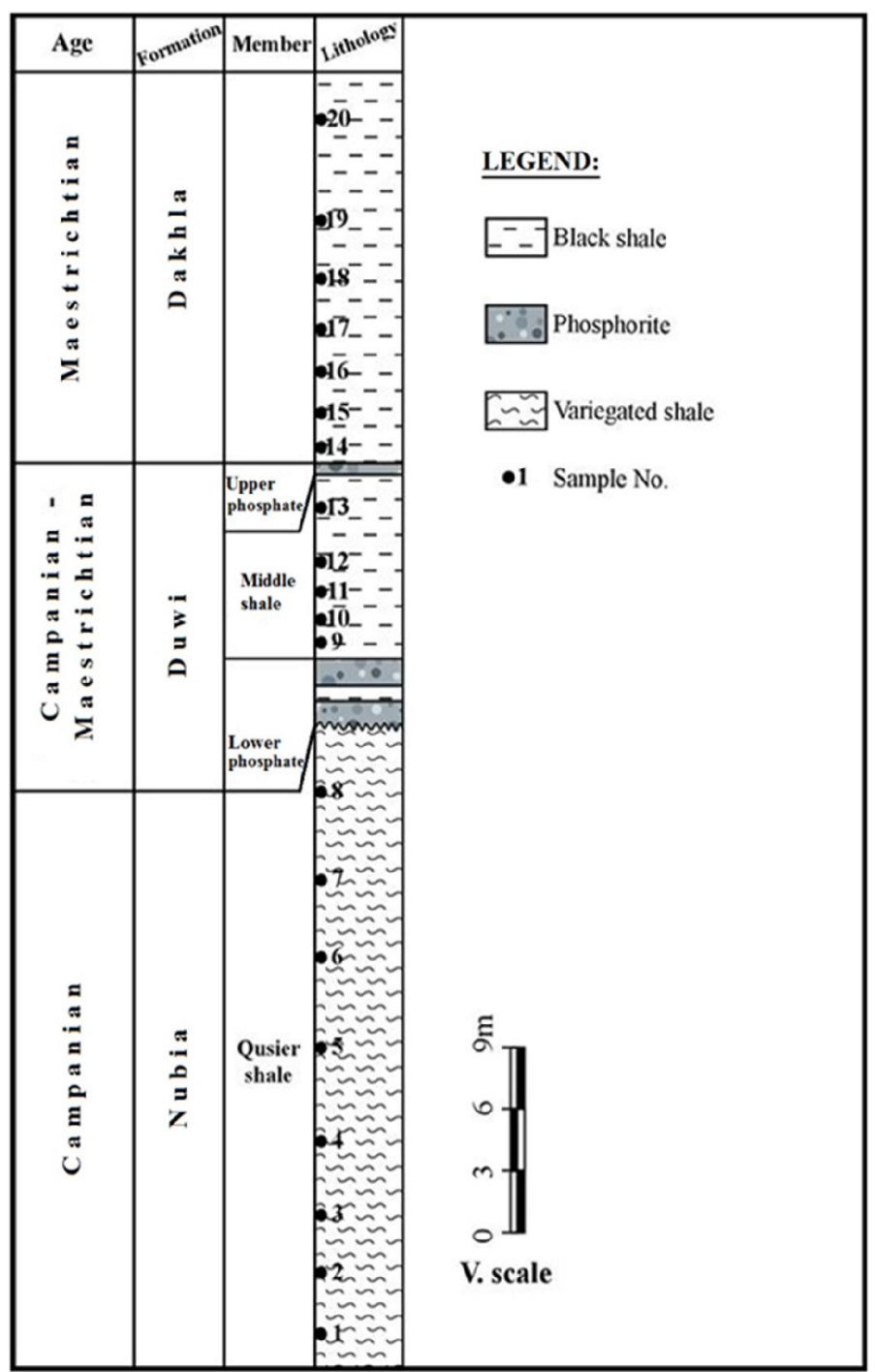

Fig. 2: General Lithostratigraphic section of the exposed rock units of the El Zayat area, southern scarp at the central part of Abu Tarur Plateau.

\section{The Upper Phosphorite Member}

This member is composed of hard dolomitic phosphorite beds intercalated with grey to thin black shale lenses. Its total thickness varies from 1.2 to $1 \mathrm{~m}$ with an average of 1 meter (Fig.2).

\section{The Dakhla Formation}

The Dakhla Formation represents the top of the present section, is composed of grey to black shale, papery, cracked and filled with gypsum and ferruginous stains and has thickness varies from 15 to $30 \mathrm{~m}$ with an average $20 \mathrm{~m}$ (Fig. 2). The Phosphorite (Duwi) Formation is conformably overlain by Dakhla Formation and assigned as the Upper Campanian to Early Maastrichtian age (Hermina, 1972, Issawi et al., 1978 and 1999). Obviously, the deposition represents an initial stage of the late Cretaceous marine transgression in Egypt.

\section{Sampling and Analytical Techniques}

Twenty representative shale samples were collected from an exposed vertical stratigraphic section of El Zayat area (8 samples from Quseir shale Member of Nubia Formation, 5 samples from Duwi Formation and 7 samples from Dakhla Formation). They used to describe all the exposed shale beds in the entire succession of the studied area. These samples were prepared and subjected to complete wet chemical analyses to estimate their major oxides while the trace elements were 
measured by using XRF (X-ray fluorescence) Philips X-ray spectrometer. On the other hand, the uranium contents were determined radiometrically by using the gamma-ray spectrometer, as well as chemically by spectrophotometeric technique using arsenazo III as an indicator.

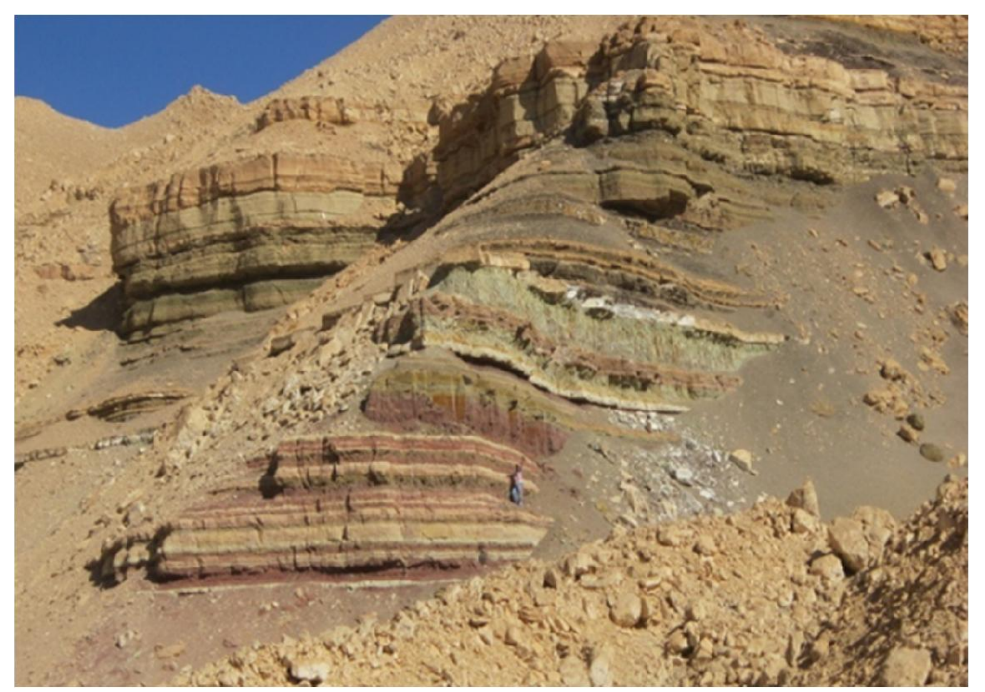

Fig. 3: Photograph showing the variegated shale of Quseir shale Member of Nubia Formation, El Zayat area, East Dakhla Oasis (the arrow and the man as a scale).

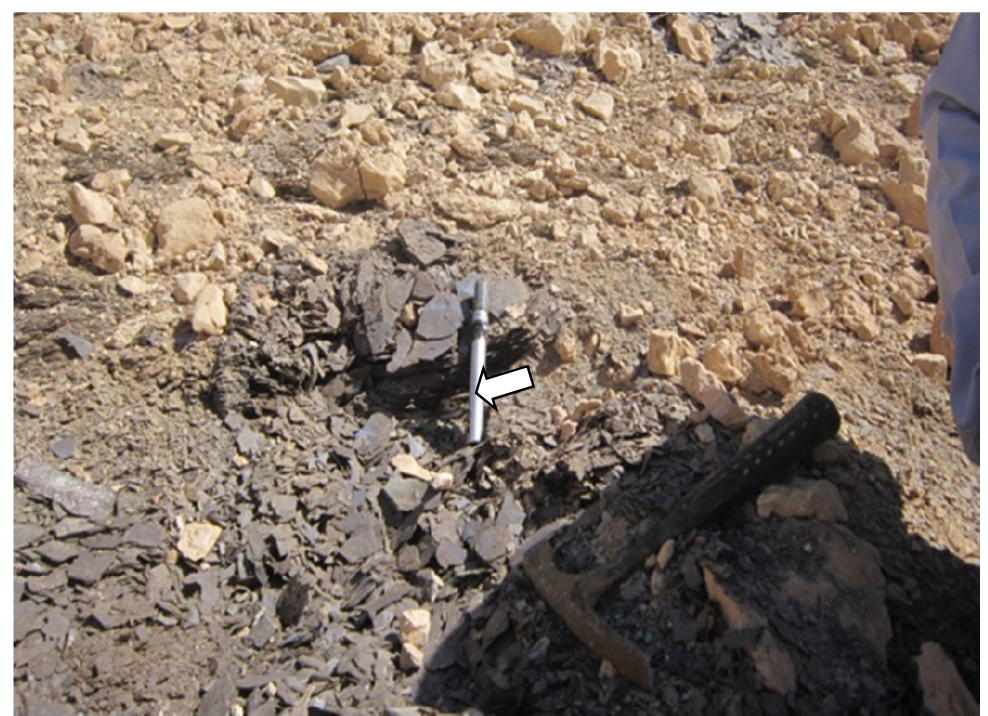

Fig. 4: Photograph showing the black shale of Middle Phosphorite Member of Duwi Formation, El Zayat area, East Dakhla Oasis.

\section{Results and Discussion}

\section{Geochemical Characteristics:}

The geochemical distribution of major and trace elements may provide direct information on the depositional environment of the host sediments (Degens et al. 1957). Indications of the depositional environment can be revealed by elements adsorbed on organic or inorganic materials from the surrounding waters. The indicators can be incorporated into primary minerals or into organic substances forming in these waters, or they can be incorporated into authigenic minerals growing within the sediments during or shortly after their deposition (Cody 1971). Zidan and Osman (2014) suggested that the immobile element values of Sibaiya shales, especially the relatively higher values 
of trace elements $(\mathrm{Cr}, \mathrm{V}, \mathrm{Ni}$ and $\mathrm{Ti})$ provide strong evidence that supports the dominance of mafic volcanic origin.

The studied shale samples of El Zayat area are subjected to chemical analyses for determining the major oxides contents (Tables 1 and 2), trace and radioactive elements (Table 3).

\section{Major Elements:}

The shale samples of El Zayat area are dominated by $\mathrm{SiO}_{2}$ with an average of $54.3 \%$ in Quseir Shale Member, $47 \%$ in Duwi Formation and $49.3 \%$ in Dakhla Formation. Also average of $\mathrm{Al}_{2} \mathrm{O}_{3}$ is $13.8 \%$ of Quseir Shale Member, $15.2 \%$ in Duwi Formation and $13.45 \%$ in Dakhla Formation (Table1). The $\mathrm{Fe}_{2} \mathrm{O}_{3}, \mathrm{MgO}, \mathrm{TiO} 2, \mathrm{Na}_{2} \mathrm{O}$ and $\mathrm{P}_{2} \mathrm{O}_{5}$ are analyzed (Table 1).

Table 1: Chemical composition as major oxides (\%) of shale samples, El Zayat area, East Dakhla Oasis.

\begin{tabular}{|c|c|c|c|c|c|c|c|c|c|c|c|}
\hline Location & S. No. & $\mathrm{SiO}_{2}$ & $\mathbf{A l}_{2} \mathrm{O}_{3}$ & $\mathrm{Fe}_{2} \mathrm{O}_{3}$ & MgO & $\mathrm{TiO}_{2}$ & $\mathrm{CaO}$ & $\mathrm{Na}_{2} \mathrm{O}$ & $\mathrm{K}_{2} \mathrm{O}$ & $\mathbf{P}_{2} \mathbf{O}_{5}$ & L.O.I. \\
\hline & 1 & 56.2 & 16.8 & 5.2 & 0.6 & 0.5 & 0.3 & 1.6 & 2.5 & 0.3 & 17.5 \\
\hline & 2 & 57.1 & 17.6 & 6.8 & 2.1 & 0.8 & 0.3 & 1.2 & 3.1 & 0.2 & 16.1 \\
\hline & 3 & 55.7 & 12.2 & 4.9 & 1.5 & 0.7 & 0.4 & 1.3 & 1.5 & 0.3 & 11.5 \\
\hline Quseir & 4 & 57.3 & 14.1 & 4.1 & 0.9 & 0.8 & 0.2 & 1.2 & 1.2 & 0.2 & 17.7 \\
\hline Shale & 5 & 58.6 & 11.3 & 4.8 & 0.8 & 0.8 & 0.4 & 1.7 & 1.3 & 0.2 & 14.3 \\
\hline \multirow[t]{6}{*}{ Member } & 6 & 45.3 & 11.2 & 18 & 0.9 & 0.8 & 2.3 & 1.2 & 1.1 & 0.6 & 15.8 \\
\hline & 7 & 54.1 & 11.3 & 17 & 0.5 & 0.6 & 1.3 & 1.2 & 2 & 0.5 & 12.1 \\
\hline & 8 & 50.4 & 16.1 & 12 & 0.2 & 0.3 & 0.6 & 1.3 & 3 & 0.2 & 14.6 \\
\hline & Aver. & 54.3 & 13.8 & 9.1 & 0.94 & 0.66 & 0.73 & 1.4 & 2.1 & 0.31 & 15 \\
\hline & 9 & 47.3 & 15.2 & 8.3 & 1.4 & 1.5 & 2.1 & 1.2 & 1.6 & 2.3 & 16.4 \\
\hline & 10 & 48.1 & 16.1 & 7.5 & 1.2 & 2 & 2.6 & 1.4 & 1.5 & 2.1 & 17.1 \\
\hline Duwi & 11 & 45.2 & 15.3 & 9.8 & 3.4 & 0.5 & 2.9 & 1.3 & 2.1 & 1.8 & 18.4 \\
\hline \multirow[t]{6}{*}{ Formation } & 12 & 46.4 & 15.1 & 10.2 & 2 & 0.8 & 2.1 & 1.1 & 1.2 & 2.8 & 16.1 \\
\hline & 13 & 48.1 & 15.2 & 7.6 & 1.5 & 1.9 & 2.5 & 1.6 & 1.7 & 1.4 & 14.5 \\
\hline & Aver. & 47 & 15.2 & 8.7 & 1.9 & 1.34 & 2.44 & 1.3 & 1.6 & 2.1 & 16.5 \\
\hline & 14 & 44.7 & 13.1 & 8.6 & 1.3 & 0.8 & 2.9 & 1.6 & 1.4 & 1.2 & 13.2 \\
\hline & 15 & 51.2 & 10.4 & 4.6 & 2.8 & 1.3 & 2.5 & 1.3 & 1.5 & 1.3 & 12.1 \\
\hline & 16 & 48.5 & 14.1 & 8.5 & 3.4 & 1.2 & 2.8 & 1.4 & 1.3 & 1.5 & 17.5 \\
\hline Dakhla & 17 & 51.2 & 15.1 & 6.2 & 2 & 1.3 & 3.1 & 1.3 & 1.6 & 1.4 & 16.9 \\
\hline \multirow[t]{4}{*}{ Formation } & 18 & 50.1 & 15.2 & 7.1 & 3 & 1.3 & 2.5 & 1.2 & 1.5 & 1.3 & 13.5 \\
\hline & 19 & 50 & 11.4 & 4.8 & 2.3 & 1.1 & 2.2 & 1.3 & 1.4 & 1.4 & 13.9 \\
\hline & 20 & 49.4 & 14.8 & 7.2 & 2.5 & 1.2 & 2.8 & 1.3 & 1.5 & 1.8 & 16.9 \\
\hline & Aver. & 49.3 & 13.45 & 6.71 & 2.47 & 1.17 & 2.7 & 1.3 & 1.5 & 1.41 & 14.85 \\
\hline
\end{tabular}

L.O.I $=$ Loss of ignition.

The average content of $\mathrm{SiO}_{2}$ in the studied shales $50.1 \%$ is lower than average of Abu Tartur black shale 52.3\% according to Zidan (2002), world shale 58.1\% according Pettijohn (1975), UCC $66 \%$ and PAAS $62.4 \%$ according (Taylor and McLennan, 1985) but slightly higher than that of the average Sibaiya black shale of Duwi Formation $49 \%$ according to (Zidan and Osman, 2014) as shown in (Table 2).

On the other hand the average content of $\mathrm{Al}_{2} \mathrm{O}_{3}$ in the studied shales $14.15 \%$ which is lower than average of Abu Tartur black shale 11.5 according to Zidan (2002), Pettijohn (1975) gave $15.40 \%$, UCC $15.5 \%$ and PAAS $18.7 \%$ according to (Taylor and McLennan, 1985) but slightly higher than that of the average Sibaiya black shale of Duwi Formation $13 \%$ according to (Zidan and Osman, 2014) as shown in (Table 2).

\section{Trace and radioactive Elements:}

The analyzed samples of El Zayat shales (Table 3) show a high relative abundance of $\mathrm{V}, \mathrm{Cr}, \mathrm{Pb}$ and Ni elements. This may be attributed to the presence of mafic components in the source rocks (Zidan and Osman, 2014). The $\mathrm{V} / \mathrm{Cr}$ ratio has been used as a paleo-oxygenation indicator in a number of studies. Values of $\mathrm{V} / \mathrm{Cr}>2$ are thought to represent anoxic depositional conditions, whereas values below 2 are indicative of more oxidizing conditions (Dill et al. 1988). The average values of $\mathrm{V} / \mathrm{Cr}$ in 
the studied shales are higher than 2 (Table 4), which may indicate that all of the studied sediments were deposited under anoxic depositional conditions. Stow and Atkin (1987) stated that the V is enriched in organic rich shale were deposited under reducing conditions and might also be hosted by detrital silicate minerals.

Table 2: Comparison of average major oxides (\%) of the El Zayat shales with other Egyptian and world shales.

\begin{tabular}{|c|c|c|c|c|c|c|c|c|c|}
\hline \multirow[b]{2}{*}{ Locality } & \multicolumn{4}{|c|}{ Present Study } & \multirow[b]{2}{*}{$\begin{array}{c}\text { Abu } \\
\text { Tartur }\end{array}$} & \multirow[b]{2}{*}{$\begin{array}{c}\text { Sibaiya } \\
\text { Shale }\end{array}$} & \multirow[b]{2}{*}{ UCC } & \multirow[b]{2}{*}{ PAAS } & \multirow[b]{2}{*}{$\begin{array}{c}\text { Pettijohn } \\
\text { Shale }\end{array}$} \\
\hline & $\begin{array}{c}\text { Quseir Shale } \\
\text { Mem. }\end{array}$ & $\begin{array}{l}\text { Duwi } \\
\text { Form. }\end{array}$ & $\begin{array}{l}\text { Dakhla } \\
\text { Form. }\end{array}$ & Aver. & & & & & \\
\hline $\mathrm{SiO}_{2}$ & 54.3 & 47 & 49 & 50.1 & 53.3 & 49 & 66 & 62.4 & 58.1 \\
\hline $\mathrm{Al}_{2} \mathrm{O}_{3}$ & 13.8 & 15.2 & 13.45 & 14.15 & 11.5 & 13 & 15.5 & 18.7 & 15.40 \\
\hline $\mathrm{Fe}_{2} \mathrm{O}_{3}$ & 9.1 & 8.7 & 6.71 & 8.17 & 13 & 11 & 4.8 & 7.2 & 4.02 \\
\hline MgO & 1.94 & 1.9 & 2.47 & 2.1 & 0.6 & 0.7 & 2.2 & 2.2 & 2.44 \\
\hline $\mathrm{TiO}_{2}$ & 0.66 & 1.34 & 1.17 & 1 & 1 & 0.6 & 0.5 & 0.1 & - \\
\hline $\mathrm{CaO}$ & 0.73 & 2.44 & 2.7 & 3.3 & 4.3 & 5 & 4.2 & 1.9 & 3.11 \\
\hline $\mathrm{Na}_{2} \mathrm{O}$ & 1.4 & 1.3 & 1.3 & 1.3 & 1 & 1.2 & 3.9 & 1.2 & 1.3 \\
\hline $\mathrm{K}_{2} \mathrm{O}$ & 2.1 & 1.6 & 1.5 & 1.7 & 1.8 & 1.6 & 4.3 & 3.7 & 3.24 \\
\hline $\mathrm{P}_{2} \mathrm{O}_{5}$ & 0.31 & 2.1 & 1.41 & 1.27 & 2.2 & & & - & - \\
\hline CIA \% & 75.3 & 74 & 73 & 74.1 & - & 79 & 58 & 75.6 & - \\
\hline
\end{tabular}

CIA = Chemical index of alteration Nesbitt and Young (1989); UCC: Upper Continental Crust and Post-Archaean Australian Shale (PAAS) is reported by (Taylor and McLennan, 1985); **: Composite 40 shales, mainly N. American Gromet et al. (1984). (in Nyakairu and Koeberl, 2001); Abu Tartur black shale (Zidan, 2002); Sibaiya black shale of Duwi Formation (Zidan and Osman, 2014) and Pettijohn shale (1975).

Table 3: Concentrations of some heavy metals and radionuclides (ppm) of shale samples of El Zayat area, East Dakhla Oasis.

\begin{tabular}{|c|c|c|c|c|c|c|c|c|c|c|c|c|c|c|c|}
\hline & S. No. & Co & $\mathrm{Cr}$ & $\mathrm{Cu}$ & $\mathbf{N i}$ & $\mathbf{P b}$ & $\mathbf{V}$ & $\mathrm{V} / \mathrm{Cr}$ & $\mathbf{c U}$ & $\mathbf{e U}$ & eTh & eRa & cU/eTh & eU/eRa & $\mathrm{cU} / \mathrm{eU}$ \\
\hline & 1 & 17 & 82 & 27 & 41 & 47 & 335 & 4 & 14 & 9 & 6 & 3 & 2.33 & 3 & 1.6 \\
\hline & 2 & 21 & 71 & 32 & 53 & 60 & 251 & 3.5 & 12 & 7 & 8 & 2 & 1.5 & 3.5 & 1.7 \\
\hline & 3 & 5 & 92 & 28 & 57 & 81 & 303 & 3.3 & 13 & 8 & 6 & 4 & 2.16 & 2 & 1.6 \\
\hline Quseir & 4 & 16 & 21 & 23 & 25 & 78 & 281 & 3.4 & 12 & 7 & 6 & 3 & 2 & 2.5 & 1.7 \\
\hline Shale & 5 & 6 & 74 & 25 & 21 & 51 & 336 & 4.5 & 14 & 9 & 4 & 3 & 3.5 & 3 & 1.6 \\
\hline \multirow[t]{6}{*}{ Member } & 6 & 8 & 72 & 19 & 57 & 66 & 383 & 5.3 & 17 & 11 & 8 & 3 & 2.12 & 3.7 & 1.5 \\
\hline & 7 & 21 & 74 & 33 & 51 & 55 & 362 & 5 & 13 & 9 & 8 & 2 & 1.62 & 4.5 & 1.4 \\
\hline & 8 & 24 & 80 & 24 & 62 & 23 & 391 & 4.5 & 14 & 10 & 7 & 3 & 2 & 3.3 & 1.4 \\
\hline & Aver. & 14.8 & 70.8 & 26.4 & 45.8 & 46 & 330.3 & 3.3 & 13.6 & 8.8 & 6.6 & 3 & 2.1 & 3 & 1.5 \\
\hline & 9 & 18 & 88 & 31 & 43 & 44 & 315 & 3.6 & 15 & 12 & 9 & 2 & 2 & 7.5 & 1.2 \\
\hline & 10 & 21 & 54 & 38 & 61 & 47 & 295 & 4.5 & 17 & 13 & 7 & 2 & 2.71 & 6.5 & 1.5 \\
\hline Duwi & 11 & 16 & 91 & 24 & 59 & 41 & 311 & 3.4 & 13 & 15 & 6 & 3 & 3.33 & 8 & 1.3 \\
\hline \multirow[t]{6}{*}{ Formation } & 12 & 17 & 73 & 30 & 41 & 43 & 286 & 3.9 & 12 & 11 & 10 & 4 & 1.6 & 4.7 & 1.4 \\
\hline & 13 & 20 & 70 & 36 & 54 & 45 & 290 & 4.1 & 16 & 12 & 8 & 2 & 2.12 & 6 & 1.4 \\
\hline & Aver. & 18.4 & 75.2 & 31.8 & 51.6 & 44 & 299 & 3.9 & 14.6 & 12.6 & 8 & 2.6 & 1.8 & 4.8 & 1.2 \\
\hline & 14 & 21 & 89 & 35 & 47 & 69 & 321 & 2.2 & 11 & 8 & 4 & 2 & 2.75 & 4 & 1.4 \\
\hline & 15 & 22 & 75 & 34 & 51 & 58 & 314 & 2.1 & 14 & 9 & 8 & 2 & 1.75 & 4.5 & 1.6 \\
\hline & 16 & 34 & 68 & 21 & 63 & 53 & 310 & 2.1 & 12 & 7 & 7 & 2 & 1.71 & 3.5 & 1.7 \\
\hline Dakhla & 17 & 23 & 54 & 29 & 56 & 34 & 301 & 2.3 & 11 & 9 & 5 & 3 & 2.2 & 3 & 1.2 \\
\hline \multirow{4}{*}{ Formation } & 18 & 19 & 73 & 31 & 59 & 27 & 299 & 2.3 & 12 & 7 & 6 & 3 & 2 & 3.5 & 1.7 \\
\hline & 19 & 23 & 62 & 32 & 54 & 65 & 309 & 2.2 & 13 & 8 & 8 & 2 & 1.6 & 4 & 1 \\
\hline & 20 & 24 & 61 & 27 & 57 & 36 & 303 & 2.3 & 12 & 7 & 5 & 1 & 2.4 & 7 & 1.7 \\
\hline & Aver. & 23.7 & 68.9 & 29.8 & 55.3 & 49 & 308 & 2.2 & 12 & 7.8 & 6 & 3 & 2 & 2.6 & 1.5 \\
\hline
\end{tabular}

On the other hand the concentrations of $\mathrm{Cr}$ and $\mathrm{Ni}$ in shale are further reflected the incorporation of $\mathrm{Cr}$ and $\mathrm{Ni}$ ions to clay particles during the weathering of mafic rocks containing chromite and other $\mathrm{Cr}$ and Ni-bearing minerals (Garver et al.1996). The $\mathrm{Cr} / \mathrm{Ni}$ ratios in the studied shales of El Zayat area of about 1.5 (Table 4), may reflect that the mafic to mafc components were the main components among the basaltic source rocks. 
The radiometric eU content of El Zayat shale samples ranges between 2 and $17 \mathrm{ppm}$ with an average of $8 \mathrm{ppm}$, while chemically it attains a value between $3 \mathrm{ppm}$ and $18 \mathrm{ppm}$ with an average 12ppm (Table 3).

Table 4: Comparison of average heavy metals and radionuclides (ppm) of shale samples of El Zayat area with other Egyptian and world shales.

\begin{tabular}{ccccccccc}
\hline Locality & $\begin{array}{c}\text { Quseir Shale } \\
\text { Member }\end{array}$ & $\begin{array}{c}\text { Present Study } \\
\text { Duwi } \\
\text { Formation }\end{array}$ & $\begin{array}{c}\text { Dakhla } \\
\text { Formation }\end{array}$ & $\begin{array}{c}\text { Abu } \\
\text { Aver. }\end{array}$ & $\begin{array}{c}\text { Tartur } \\
\text { Sibaiya shale }\end{array}$ & UCC & PAAS \\
\hline $\mathbf{C r}$ & 70.8 & 75.2 & 67.3 & 71 & 95 & 148 & 35 & 110 \\
$\mathbf{C u}$ & 26.4 & 31.8 & 34.8 & 31 & 65 & 31 & 13 & 50 \\
$\mathbf{N i}$ & 45.8 & 51.6 & 55.3 & 51 & 42 & 51 & 20 & 55 \\
$\mathbf{P b}$ & 46 & 44 & 49 & 46 & 37 & - & 14 & - \\
$\mathbf{V}$ & 330 & 299 & 308 & 312 & 257 & 136 & 60 & 150 \\
$\mathbf{C r} / \mathbf{N i}$ & 1.6 & 1.5 & 1.2 & 1.5 & - & - & - & - \\
$\mathbf{V} / \mathbf{C r}$ & 4.7 & 4 & 4.6 & 4.4 & 2.7 & 0.9 & 1.7 & 1.4 \\
$\mathbf{c U}$ & 13.6 & 14.6 & 12 & 13.4 & 9 & 9.3 & - & - \\
$\mathbf{e U}$ & 8.8 & 12.6 & 7.8 & 9.7 & - & 6.4 & - & - \\
$\mathbf{e T h}$ & 6.6 & 8 & 6 & 6.9 & - & 6.3 & - & - \\
$\mathbf{e R a}$ & 3 & 2.6 & 3 & 2.9 & - & 4.3 & - & - \\
$\mathbf{c U} / \mathbf{e T h}$ & 2.1 & 2.3 & 2 & 2.1 & - & - & - & - \\
$\mathbf{e U} / \mathbf{e R a}$ & 3 & 4.8 & 2.6 & 3.5 & - & - & - & - \\
$\mathbf{c U} / \mathbf{e U}$ & 1.6 & 1.2 & 1.5 & 1.4 & - & - & - & - \\
\hline
\end{tabular}

Abu Tartur $=$ average of black shale (Zidan, 2002); Sibaiya $=$ average of black shale of Duwi Formation (Zidan and Osman, 2014); UCC = Upper Continental Crust and Post-Archaean Australian Shale (PAAS) is reported by (Taylor and McLennan, 1985).

\section{Chemical Mobility and Weathering Trends:}

The geochemical composition of the different weathering products depends largely upon the rate of weathering and it is expected to demonstrate well established concepts of mobility of elements during weathering and therefore to assess the state of chemical weathering (Singh et al., 2005). The preferential removal of $\mathrm{CaO}, \mathrm{Na}_{2} \mathrm{O}$ and $\mathrm{K}_{2} \mathrm{O}$ by solution during weathering processes (Nesbitt and Young, 1989) due to their high mobility means that the abundance of these elements with respect to less easily removed elements can be used as a measure of the extent of geochemical weathering in provenance. Since Al element in the feldspars is the least mobile element. Nesbitt and Young (1989) proposed a chemical index of alteration (CIA) where:

$\mathrm{CIA}=\left[\mathrm{Al}_{2} \mathrm{O}_{3} /\left(\mathrm{Al}_{2} \mathrm{O}_{3}+\mathrm{CaO}+\mathrm{Na}_{2} \mathrm{O}+\mathrm{K}_{2} \mathrm{O}\right)\right] \times 100$

The CIA enables the estimation of the intensity of weathering in the sedimentary deposits, or it may be used to compare the relative proportions of chemically weathered material present in a sample. According to Nesbitt and Young (1989);

- Average CIA\% value ranges from 50-60 reflects a weak chemical weathering degree.

- Average CIA\% value ranges from 60-80 indicates moderate degree of weathering.

- Average CIA\% value ranges from 80-100 means intensive weathering.

In the investigated samples of Quseir Shale Member of Nubia Formation, Duwi and Dakhla Formations, the recorded CIA average values are $75.3 \%, 74 \%$ and $73 \%$, respectively (Table 2). In addition to the average values CIA\% of El Zayat shales are higher than UCC value (58\% according to Taylor and McLennan, 1985) and lower than Sibaiya black shale of Duwi Formation (79\% according to Zidan and Osman, 2014) suggest that the moderate chemical weathering of the source rocks under tropical to subtropical humid climatic conditions. Beside, the fluviatile of post deposition contributions from local sources, such as the basement rocks in the Egyptian South Western Desert, can be considered as subordinate sources.

On the other hand the (cU/Th) ratios in shales of Quseir Shale Member, Duwi Formation and Dakhla Formation of El Zayat area are (2.1, 2.3 and $2 \mathrm{ppm}$, respectively) indicate a higher degree of uranium mobilization and deposition enrichment. While, the equilibrium factor P-Factor (eU/Ra) was 
more than one (3, 4.8 and $2.6 \mathrm{ppm})$, indicating a possible deposition enrichment of uranium in a disequilibrium state (Naumov, 1959). Also, these results were confirmed by the calculation of DFactor $(\mathrm{cU} / \mathrm{eU})$ which is mainly more than one (1.6, 1.2 and 1.5ppm), showing distinct disequilibrium state with the addition of younger uranium (Adams and Weaver, 1958).

\section{Determination of the Provenance and Tectonic Setting:}

The type of the provenance of shales in El Zayat area depends largely upon its position to an adjacent tectonic setting and the comparison between their chemical compositions with those of sediments deposited in this known tectonic setting. Roser and Korsch (1988) proposed a tectonic classification based on $\mathrm{SiO}_{2}$ content and $\log \left(\mathrm{K}_{2} \mathrm{O} / \mathrm{Na}_{2} \mathrm{O}\right)$ ratios as described in (Fig. 5) dividing the tectonic origin into three provinces. The application of this classification to El Zayat shales indicates that these ratios fall in the field of arc of provenance, this indicate the El Zayat shales are mainly derived from volcanic rocks. In order to support this classification the following tests were applied using the upper continental crust normalization pattern and the immobile element correlation with the UCC.

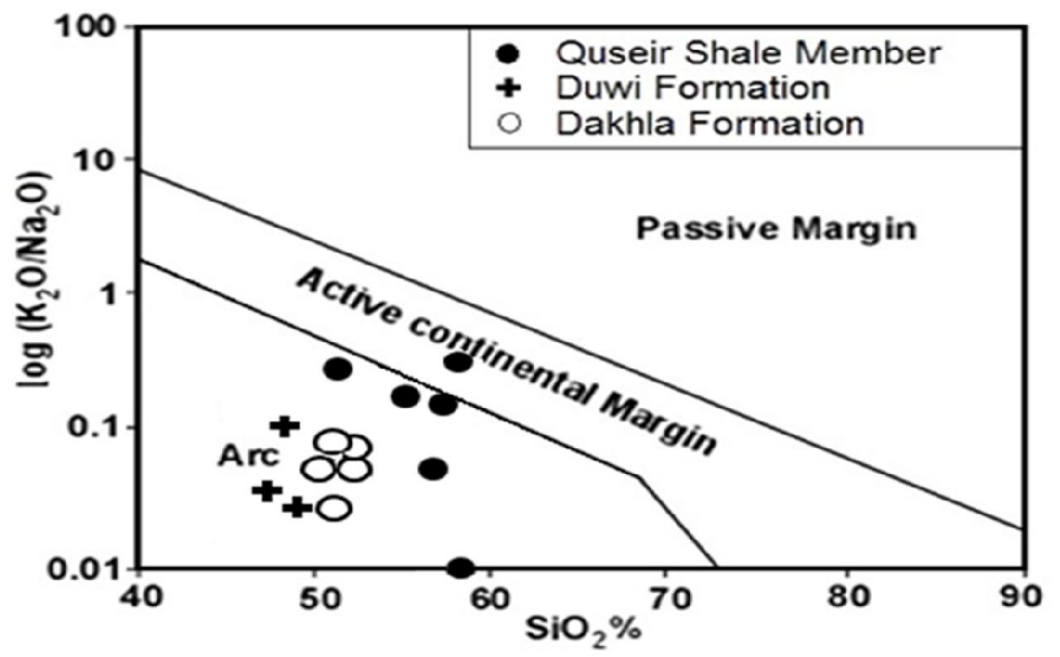

Fig. 5: Tectonic discrimination diagram for El Zayat shale samples. Lines are placed according to (Roser and Korsch, 1988).

\section{Upper Crust Normalized Pattern:}

Concentrations of the major and trace elements of the investigated shale samples of El Zayat area have been normalized to the average Upper Continental Crust (UCC) values according to (Taylor and McLennan, 1985). The UCC normalized pattern for the studied samples (Fig. 6) can be classified into three classes:

- The first class comprises elements being highly dominant relative to the UCC values (e.g. $\mathrm{Cr}, \mathrm{Cu}$, $\mathrm{Ni}, \mathrm{Pb}, \mathrm{Fe}_{2} \mathrm{O}_{3}, \mathrm{TiO}_{2}$ and $\mathrm{V}$ ). The dominance of these elements may be attributed to the occurrence of mafic components in the source rocks.

- The second class consists of most major elements $\mathrm{SiO}_{2}, \mathrm{Al}_{2} \mathrm{O}_{3}$ and $\mathrm{MgO}$. These elements in the investigated samples are relatively near to the UCC values. This may be due to the efficient mixing of sedimentary material during weathering of the source rock, transportation and deposition in the study area. Therefore the UCC origin of the provenance is shifting towards a more basic tectonic origin is strongly recommended.

- The third class comprises the major elements, $\mathrm{CaO}, \mathrm{Na}_{2} \mathrm{O}$ and $\mathrm{K}_{2} \mathrm{O}$. These elements are relatively lower compared to the UCC values. These elements are susceptible to mobility during weathering processes due to their high hydration energies (Cullers, 2000). 


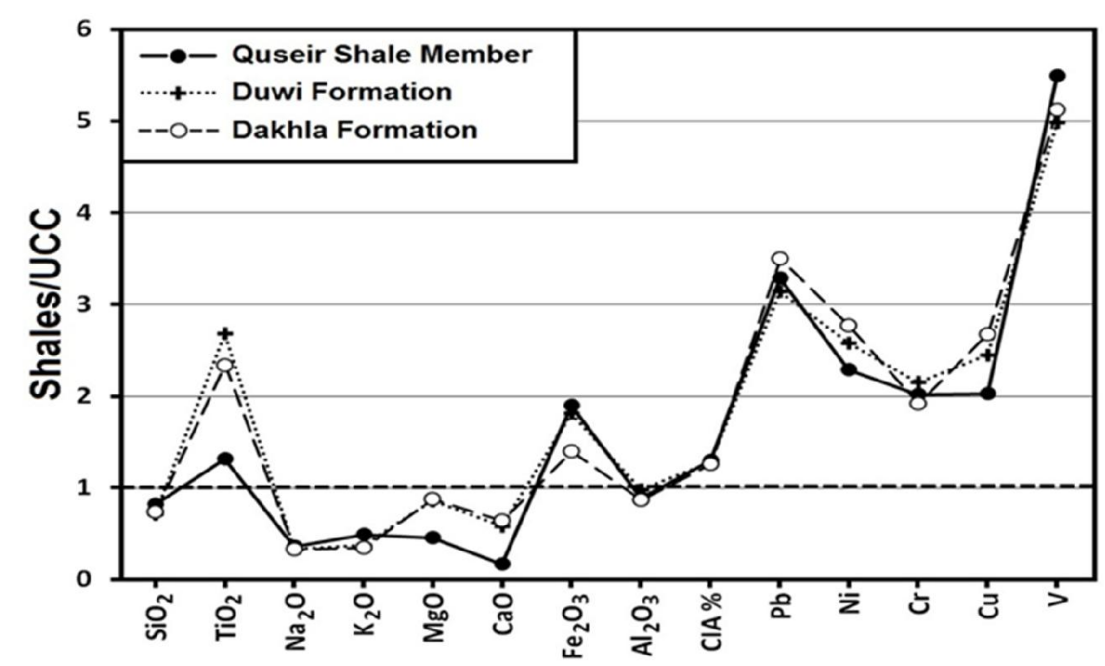

Fig. 6: UCC normalized for major and trace studied elements of El Zayat shale samples.

\section{Provenance and Immobile Elements:}

Singh et al. (2005) indicated that the geochemical composition of siliclastic sediments results from a complex interplay between provenance and processes that operate during the different stages of the sedimentary cycle. In addition, the immobile elements are also indicators of the origin of the provenance. Therefore, the presence of trace elements $\mathrm{Cr}, \mathrm{V}$ and $\mathrm{Ni}$ in addition to Ti suggests a volcanic origin of El Zayat shales. This conclusion was confirmed by (Taylor and McLennan, 1985). (Table 2) shows that the average values of $\mathrm{TiO}_{2} / \mathrm{Al}_{2} \mathrm{O}_{3}$ ratios for most of the investigated sediments lie around a value (0.1), which is similar to that of basaltic source and higher than the corresponding values for UCC, NASC, and PAAS (Fig. 7).

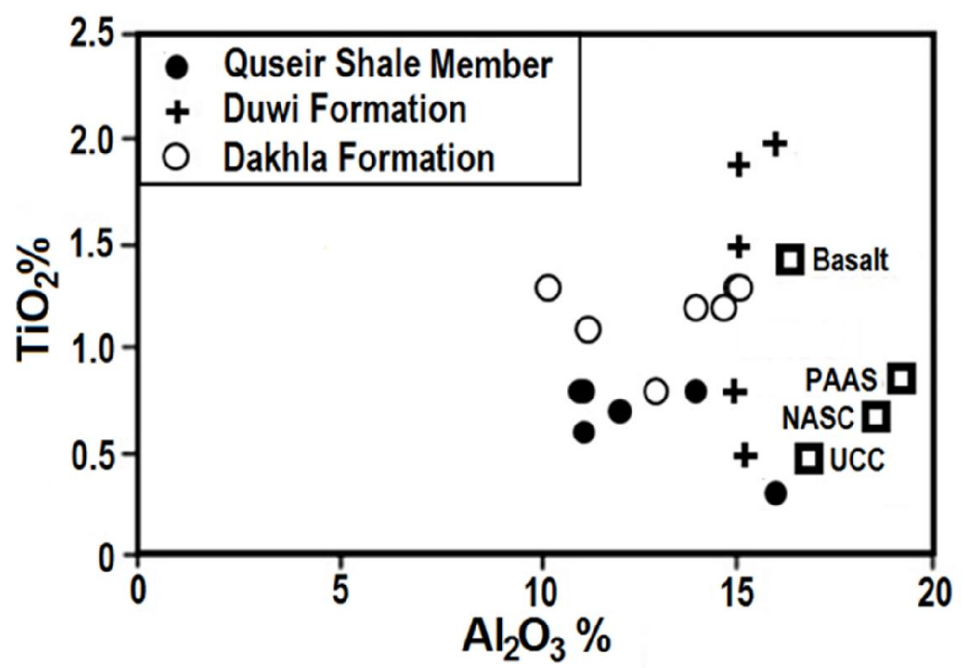

Fig. 7: Relationship between $\mathrm{TiO}_{2}$ and $\mathrm{Al}_{2} \mathrm{O}_{3} \%$ for average values $\mathrm{El}$ Zayat shale samples compared with that of UCC, NASC and PAAS.

\section{Geo-accumulation Index and Pollution Pattern:}

The index of geo-accumulation (Igeo) proposed by Müller (1969) has been used widely to assess of soil and sediment contamination Graver et al. (1996) and Loska et al. (2004). This index is computed using the following equation:

Igeo $=\log 2(\mathrm{Cn} / 1.5 \mathrm{Bn})$. Where $\mathrm{Cn}$ is the measured concentration of a given metal in sediment and $\mathrm{Bn}$ represents the geochemical background concentration of it. Under normal environmental conditions, the natural concentrations of elements in sediments have a usual characteristic pattern of distribution. However, the environmental pollution from domestic, 
agricultural, and industrial wastes and also the natural input cause an abnormal concentration of some of the major and trace element contents in a sediment and consequent disturbance these natural relationships. The disturbance of the natural geochemical patterns of association accompanied by mineralogical and textural differences may indicate an anthropogenic or natural input. In the present study the concentrations of elements in the UCC (Taylor and McLennan,1985) were used as background values. According to Müller (1969) the geo-accumulation index in relation to pollution extent is classified into seven classes (Table 5).

In El Zayat shale samples the results of geo-accumulation index of the Quseir Shale Member of Nubia Formation, Duwi and Dakhla Formations show that the V content $(0.12,0.26$ and 0.22 , respectively), $\mathrm{Cu}(1.07,0.80$ and 0.90 , respectively), $\mathrm{Pb}(0.46,0.52$ and 0.37 , respectively), $\mathrm{Ni}(0.74$, 0.57 and 0.47 , respectively) and $\operatorname{Cr}(0.13,0.05$ and 0.17 , respectively). Therefore, they are classified as unpolluted elements. On the other hand, Co in Duwi and Dakhla Formations is (0.29 and 0.66, respectively) reveal an unpolluted to moderately polluted element while in the Quseir Shale Member is 0.02 as unpolluted. While $U$ content in the same shale is $(0.76,0.87$ and 0.58 , respectively), $U$ is the element being considered as unpolluted to moderately polluted element (Table 5). The recorded moderately polluted characters recorded in the investigated shale samples are most probably attributed to the natural weathering of the source rocks rather than artificial input. The relative abundance of $\mathrm{Cr}$ is most probably due to substitution of $\mathrm{Cr}$ with iron in the structure of the ferromagnesian silicate minerals. The industries and the agricultural wastes are nearly absent in the study area since it occurs in remote desertic area and therefore, it is suggested that the anthropogenic input is rather limited. In general the geo-accumulation indices (Igeo) indicate that the El Zayat shales are mainly low to moderately pollute. However, their utility in domestic purposes is safe if the dilution factor in the final product is proper.

Table 5: The geo-accumulation index (Igeo) of El Zayat shales, East of Dakhla Oasis.

\begin{tabular}{|c|c|c|c|c|}
\hline \multirow{2}{*}{$\begin{array}{l}\text { Range } \\
(\mathbf{p p m})\end{array}$} & \multirow[b]{2}{*}{ Degree of pollution } & \multicolumn{3}{|c|}{ Average elements in the studied area } \\
\hline & & $\begin{array}{c}\text { Quseir Shale } \\
\text { Member }\end{array}$ & Duwi Formation & Dakhla Formation \\
\hline$<0$ & Unpolluted & $\mathrm{Pb}, \mathrm{Ni}, \mathrm{Cr}, \mathrm{Cu}, \mathrm{V}, \mathrm{Co}$ & $\mathrm{Pb}, \mathrm{Ni}, \mathrm{Cr}, \mathrm{Cu}, \mathrm{V}$ & $\mathrm{Pb}, \mathrm{Ni}, \mathrm{Cr}, \mathrm{Cu}, \mathrm{V}$ \\
\hline $0-1$ & Unpolluted to moderately polluted & $\mathrm{U}$ & Co, $U$ & $\mathrm{U}, \mathrm{Co}$ \\
\hline $1-2$ & Moderately polluted & - & - & - \\
\hline $2-3$ & Moderately to strongly polluted & - & - & - \\
\hline $3-4$ & Strongly polluted & - & - & - \\
\hline $4-5$ & Strongly to very strongly polluted & - & - & - \\
\hline$>5$ & Very strongly polluted & - & - & - \\
\hline
\end{tabular}

\section{Conclusion}

1- Twenty representative shale samples were collected from a vertical lithostratigraphic section including (Quseir Shale Member of Nubia Formation, Duwi Formation and Dakhla Formation) of El Zayat area on the southern scarp at the central part of the Abu Tartur Plateau.

2- The values of $\mathrm{V} / \mathrm{Cr}$ in the studied shales are higher than 2, which may indicate that all of the studied sediments were deposited under anoxic depositional conditions.

3- The $\mathrm{Cr} / \mathrm{Ni}$ ratios of El Zayat shales are 1.5, may be reflect these sediments are derived from volcanic source rocks. Also the tectonic setting studies indicated that the investigated studied shales were mainly derived from volcanic rocks an arc province origin.

4- The chemical Index of alteration (CIA) was calculated for all the samples and revealed that El Zayat shales describe the moderate chemically weathered terrain. Beside, the fluviatile of post deposition contributions from local sources, such as the basement rocks in the Egyptian South Western Desert, can be considered as subordinate sources.

5- The immobile elements are also indicators of the origin of the provenance. Therefore, the presence of trace elements $\mathrm{Cr}, \mathrm{V}$ and $\mathrm{Ni}$ in addition to $\mathrm{Ti}$ in $\mathrm{El}$ Zayat shales suggests a basaltic source origin.

6- Additional environmental investigations were also undertaken in order to explore any environmental radiation impact that may arise from the utility of these shales in any domestic 
purposes by the locals and/ or industry. The calculation of geo-accumulation indices (Igeo) indicate that the investigated sediments in El Zayat area are mainly low to moderately pollute. However, their utility in domestic purposes is safe if the dilution factor in the final product is proper.

\section{References}

Adams, J.A., and C.E. Weaver, 1958. Thorium to uranium ratios as indicators of sedimentary examples of the concept of geochemical facies. Bull. Am. Ass. Petrol. Geol., 42: 387-430.

Cody, R.D., 1971. Adsorption and the reliability of trace elements as environment indicators for shales. J. Sed. Petrol., 41, 461-471, Tulsa.

Cullers, R.L. 2000. The geochemistry of shales, siltstones and sandstones of Pennsylvanian-ermian age, Colorado, USA: implications for provenance and metamorphic studies, Lithos, 51:181203.

Degens, E.T., E.G. Williams, and M.L. Keith, 1957. Environmental studies of Carboniferous sediments, Part I. Geochemical criteria for differentiating marine from fresh-water shales. Am. Ass. Petrol. Geol. Bull., 41, 2427-2455, Tulsa.

Dill, H., M. Teschner, and H. Wehner, 1988. Petrography, inorganic and organic geochemistry of Lower Permian carbonaceous fansequences "Brandschiefer Series", Fedral Republic of Germany: constraints to their paleogeography and assessment of their source rock potential. Chem. Geol. 67, 307-325.

Ghandour, I.M., M. Harue, and M. Wataru, 2005. Mineralogical and chemical characteristics of Bajocian-Bathonian shales, G. Al-Maghara, North Sinai, Egypt: Climatic and environmental significance. Geochemical Journal, 37: 87-108, Gromet, L.P., R.F. Dymek, L.A. Haskin, and R.L.Korotev, 1984. The "North American.

Hallam, A., J.A. Grose, and A.H. Ruffell, 2005. Paleoclimatic significance of changes in clay mineralogy across the Jurassic-Cretaceous boundary in England and France. - Palaeogeog. Palaeoclimat. Palaeoecol., 81, 173-187.

Hermina, M., 1972. Review of the phosphate deposits of Egypt. In: 2nd Arab Conference Miner. Resour., Conf. papers, 109-149.

Issawi, B., M.Y. Hassan, and A. Saad, 1978. Geology of Abu Tartur Plateau, Western Desert of Egypt.Annals Geol. Surv. Egypt. 8: 91-127.

Isawi, B.; M. El Hinnawi,.; M. Francis, and A. Mazhar, 1999. The Phanerozoic geology of Egypt. A geodynamic approach, special Pub. No.76. Geol. Survey. Cairo. Egypt.

Jeong, G.Y. and H.I. Yoon, 2001. The origin of clay minerals in soils of King George Island, South Shetland Islands, West Antarctica, and its implications for the clay mineral compositions of marine sediments. Journal of Sedimentary Research, 71(5): 833-842.

Garver, J.I., P.R. Royce, and T.A. Smick, 1996. Chromium and nickel in shale of the Taconic Foreland: A case study for the provenence of fine-grained sediments with an ultramafic source. J. Sedim. Res., 66, 100-106.

Moore, D.M. and R.C. Reynolds, 1989. X-Ray diffraction and the Identification and Analysis of Clay Minerals. -332 pp., Oxford (Oxford University Press).

Müller, G. 1969. Index of geoaccumulation in sediments of the Rhine river, Geo. J., 2: 108-118.

Naumov, G.B. 1959. Transportation of uranium in hydrothermal solution as carbonate. Geoch.V.1.P. $5-20$.

Nesbitt, H.W. and G.M. Young, 1989. Formation and diagenesis of weathering profiles, J. Geology, 97: 129- 147

Nyakairu G. W. A. and C. Koeberl 2001. Mieralogical and chemical composition and distribution of rare earth elements in clay-rich sediments from central Uganda. Geochemical Journal. 35:13 28

Pettijohn, F.J., 1975. Sdimentary Rocks. $3^{\text {rd }}$ Ed., 628 pp., New York (Harper \& Row).

Roser B. P. and R. J. Korsch 1988. Provenance signatures of sandstone- mudstone suite determined using discriminate function analysis of major element data: Chem. Geol., 67: 119-139.

Singh M, M. Sharma and H. L. Tobschall, 2005. Weathering of the Ganga alluvial plain, northern India:implications from fluvial geochemistry of the Gomati River. Appl. Geochem., 20: 1-2. 
Stow, D.A. V. and B. P. Atkin, 1987. Sediment facies and geochemistry of Upper Jurassic mud rocks in the central North Sea area. Petroleum Geology of North West Europe (Brooks J and Glennie K., eds.), 797-808, Graham and Trotman, London.

Taylor S. R. and S. M. McLennan 1985. The Continental Crust: Its Composition and Vietnam in the western South China Sea: Implications for source analysis and East Asian monsoon evolution. Sci. China Ser. D. Earth Sci., 50: 1674-1684.Weaver, C.E.,1989. Clays, Mud, and Shales: Amsterdam, Elsevier, 819.

Zidan, I.H., 2002. Geological, Mineralogical and Geochemical studies of Abu Tartur area. Western Desert, Egypt. Ph.D. Thesis, Fac. Sci., Al Azhar Univ., 235.

Zidan, I. H., 2014. Evaluation of phosphorite and Uranium in Lower phosphorite Member, Duwi Formation at Kummer area, South Esna, West Nile Valley, Egypt. Sedimentology of Egypt, Sedimentology of Egypt, 2013; 21: 143 - 154.

Zidan, I.H. and R. A. Osman, 2014. The Application of Geochemical and Mineralogical Studies of Cretaceous Shales in West Sibaiya Area, Egypt to Investigate Their Tectonic and Sedimentological Origin with Environmental Impacts, Journal of Nuclear Materials Authority. 1: 99-118.

Zidan, I.H., 2017. Evaluation of phosphorite and Uranium Resources of Duwi Formation at Helal area, South Esna, East Nile Valley, Egypt. Sedimentology of Egypt, 23: 63 - 80. 